\title{
Kristin Reynolds and Nevin Cohen, 2016, Beyond the Kale: Urban Agriculture and Social Justice Activism in New York City, Athens, The University of Georgia Press, 189 p.
}

\author{
Joshua Sbicca ${ }^{1}$
}

Published online: 22 January 2018

C INRA and Springer-Verlag France SAS, part of Springer Nature 2018

Upon first glance, an urban farm appears to jut from a landscape of concrete and steel, compelling the passerby to take stock of the abundance of plants and pollinators. Observe a little longer and the people that till the soil and foster the agricultural conditions come into focus. All abilities, ages, ethnicities, races, genders, sexualities, nationalities, and religions grow food in cities. Even municipal governments, businesses, health advocates, non-profits, and grassroots organizations throughout the USA are touting the benefits of urban agriculture for many different groups. Given the longstanding association of cities with entrenched social problems, this is a welcome respite. For some, urban agriculture may even be a key solution.

But who has the power to shape common conceptions of urban agriculture? Who do economic and political elites, funders, and the media listen to? Who receives resources to accomplish their goals? What discourses and strategies are considered legitimate? These are some of the crucial equity considerations that Kristin Reynolds and Nevin Cohen tackle in Beyond the Kale. Many previous scholarly treatments of urban agriculture focus on the pitfalls practitioners and activists face, such as land access and tenure and the technical difficulties of growing food in cities, or are overly laudatory of its environmental and social benefits. Instead, this book highlights the activism of working class people, people of color, and women in New York City to advance social justice. It proceeds by recognizing that structural forces like neoliberal capitalism can handicap or co-opt urban agriculture, but argues for an "action-oriented dialogue" about how to use urban agriculture to advance social justice. One of the strengths of the book is the articulation of what it means to engage in scholarly work as social justice praxis, what the authors refer to as an "action research project." Addressing the above questions is not an exercise in building

Joshua Sbicca

J.Sbicca@colostate.edu

1 Colorado State University, Fort Collins, CO, USA 
theory for theory's sake. It considers the real-world constraints and opportunities of conducting research with communities who want to make material improvements in their lives. This is an approach worthy of replication.

Given the pervasiveness of social inequities, the tendency of critical scholars is to emphasize the structural dimensions that shape social life. In the USA, with the election of Donald Trump and the complicit opportunism of the Republican Party, it has become even easier to fall into this critical thought trap. But urban centers are at the heart of resistance. Social justice movements are pushing local politicians to stand up for economic, racial, and environmental justice amidst the onslaught of revanchist policies. With little support at a federal level for progressive policies, including in the food system, it is important to understand how these movements strategize to advance their goals. Although this varies by city, urban agriculture is one force among many that is politically positioned to align with efforts that advance social justice. Drawing on critical race theory and theories of intersectionality, Reynolds and Cohen use a unique framework to understand the relationship between social and political structures and how urban agriculture can confront these structures. Seeing oppression as multifaceted opens the scholar and activist alike to understand that a problem like poverty affects the ability to access healthy food differently depending on one's class position, race, and/or gender. Given the current political climate these theoretical tools have practical implications for urban agriculture activists as they build alliances across different movements to advance a broader social justice agenda.

To help frame their argument, Beyond the Kale provides a history of urban agriculture in New York City. Specifically, it draws attention to the politicized realities of class and ethnoracial struggle. For example, early animal husbandry, farming, and gardening in working class communities and communities of color were eventually deemed either unhealthy or marginal forms of land use that were subservient to the development goals of New York City boosters. And like the rest of the USA during the Progressive Era and World War II, political support for urban agriculture swelled in order to instill civic values and patriotism. These political projects largely ignored the use of urban agriculture as a strategy for sustenance and community self-determination. One of the book's important revelations is that popular urban agriculture imaginaries often reflect the interests of people with greater levels of power and privilege. Look past the façade and there is a more complicated history. For example, due to the fact that working class communities and communities of color continued to foster grassroots urban agriculture initiatives, there were networks to resist the larger systems of neoliberal restructuring and institutional racism that took place from the 1970s through the 1990s. Reynolds and Cohen acknowledge that while class and ethnoracial inequities are widespread in cities that the contemporary urban agriculture system in New York City not only reproduces structural disparities but provides openings to advance social justice. They claim that to maximize the success of the urban agriculture system requires eliminating these disparities.

One of the difficulties the authors face in this book is providing insight into the relationship between the inequities that working class people and people of color experience and what constitutes successful pushback. It is clear from the testimony of black urban agriculture activists like Karen Washington that white and wealthier groups represent the face of the food movement. They receive more attention and resources and de facto legitimacy. By calling attention to how white supremacy and capitalism 
intersect to create privilege and disadvantage, the solution becomes obvious. Create equitable economic, political, and social conditions. But what are the best ways to do this? While Reynolds and Cohen articulate how radical urban agriculture activists in working class neighborhoods and neighborhoods of color engage policy makers on everything from housing and poverty to land access and community composting, this work is generally secondary to activists' prefigurative politics. After all, under-resourced groups only have so much flexibility to engage in the arduous process of political organizing when crops need cultivating. There is the added difficulty, one discussed by the authors, of competition for scarce resources by urban agriculture non-profits. This problem is made worse by class and ethnoracial disparities in who receives these resources. Although true, there was a missed opportunity to discuss a deeper reality. The nonprofitization of food movement work tends to depoliticize urban agriculture. In the USA, 501(c)(3) non-profits are mission-driven organizations that rely on outside sources of funding. This alone is a major hindrance to devising political strategies beyond the support of the institutional elites who control government and philanthropic coffers. Moreover, to maintain their tax-exempt status, a 501(c)(3) cannot have a substantial part of its work entail influencing legislation. The problems are not just that radical urban agriculture work is not funded, is harder to quantify, and must be masked to legitimate most funding, they include that the non-profit model itself is not the basis upon which radical social movements build power to achieve their goals. Mass grassroots movements need more organizational flexibility to engage in policy work.

I agree with the authors' point that an intersectional approach helps to push against the tendency by critical food scholars to overdetermine prefigurative strategies, whether market-based or not, as neoliberal. As they show with plenty of examples, growing food can be a method to resist cultural oppression and victimization and support selfdetermination. By attending to the praxis of urban agriculture initiatives by working class activists of color, we learn that anti-oppression commitments begin with creating leadership opportunities, modeling socially just organizational structures, and using liberatory pedagogical strategies. One of the historical reasons for taking the path of self-determination over political confrontation is that some groups face structural obstacles to participating in mainstream politics. Black Power groups such as the Black Panther Party were keenly aware of this. Their "survival programs" included buying food cooperatively and providing free food for those most in need "pending revolution." They demanded the elimination of capitalism, imperialism, and white supremacy, a radical project that most politicians would never support. Nevertheless, they knew that black liberation required confronting the state on many fronts, say to eliminate police brutality, to expand the conditions more amenable to their goals.

Beyond the Kale offers several contemporary examples that reflect a similar analysis, such as the work of La Unión to tie immigration advocacy to food justice work. Given that one of the main drivers of social inequity are laws and policies that actively harm or prevent the advancement of historically marginalized groups, this is an essential target for community organizing. But whereas the book provides many details of how urban agriculture initiatives contribute prefiguratively to social justice movements, it explores less of the confrontational and traditional policy work of urban agriculture activists. Although Reynolds and Cohen mention that some activists engage in conventional policy advocacy, it focuses more on network building, framing, and everyday examples that demonstrate the viability of urban agriculture to convince policy makers 
it is worth their support. Perhaps this is an artifact of urban agriculture in New York City or of the national engagement in this practice more broadly. Regardless, I was left wanting to know more about the conventional policy campaigns that tied together urban agriculture with social justice goals. The contemporary prominence of food policy councils suggests that policy advocacy is a growing concern in the food movement. On a theoretical and practical level, it is important to know more about the contentious politics of urban agriculture policy-making. If policy-making is absent, we need to know more about the operation of social and political structures. What is the role of corporate power? What are the political opportunities and constraints? How does ideology operate to (de)legitimatize urban agriculture? Tracing examples in greater detail can yield important insights. What grassroots tactics and strategies are best suited for advancing a policy framework that advances social justice through urban agriculture systems? How do working class communities and communities of color leverage their assets to build political capital that can reshape laws and policies?

As a whole, Kristin Reynolds and Nevin Cohen offer a compelling analysis that elevates the voices, struggles, and victories of urban agriculture initiatives led by women, working class people, and people of color. Not only do they contribute to critical food scholarship but also to broader debates within the food movement over power, privilege, and representation. Undergraduates and graduate students would greatly benefit from reading this book as many of them go on to participate in the food movement. There are also insights that urban agriculture activists would take away, from how to integrate anti-oppression practices to the prospects and constraints of working with academics. It is rare to find a book that reaches so many audiences. This book inspires action across divides by centering social justice to generate urgent changes to social and political structures through urban agriculture. Let us all get beyond the kale. 